\title{
Social Traditions and the Islamic Purification Movement in Indonesia
}

\author{
Dr. Sutiyono \\ Yogyakarta State Yogyakarta, Indonesia \\ Sutiyono_63@yahoo.com
}

\section{Doi:10.5901/mjss.2015.v6n2s1p251}

\begin{abstract}
The objective of the research concerned here was to describe the relation between certain traditions in society and the movement to purify Islam here in Indonesia. The supporters of the social traditions are the village farmer communities that still conduct, among others, the traditional rite of slametan. The supporters of the Islamic purification movement are pure-Islam communities that conduct Islamic penetration into the supporters of the social traditions. In conducting the penetration, the Islamic purification movement is influenced by factors of ideology and identity. The approach employed in the research was ethnographical in nature. The research results indicate that the Islamic purification movement of Muhammadiyah, in accordance with its ideology and identity, attempts to bring back pure Islamic teachings through (1) Sunday moning pengajian, (2) tarjih movement, and (3) social education. Meanwhile, the social tradition in the form of slametan is still going strong, as expressed by village communities through (1) tradition concerning ziarah, (2) tradition concerning nature, and (3) tradition concerning the human life cycle.
\end{abstract}

Keywords: social tradition, slametan, Muhammadiyah, Islamic purification

\section{Introduction}

Religious practice in Java is described by Geertz as a complex culture. He points at the great quantity of variation in rituals, conflicts in a faith, and conflicts of values that appear as consequences of difference in social class or, according to him, as cultural types like those called abangan, santri, and priyayi (Geertz, 1960: 9). ${ }^{1}$ However, though difference in cultural type results in a plural society, the different social groups are still attached to the same geographical areas. Many of the values held by social groups different in type of culture but belonging to the same social structure are the same or, in other words, there are forms of integration among them. In view of the above expositions, the study concerned here was, among others, to prove the thesis coming from Geertz (1960: 475-476) that not only religion as cultural system plays an integrative part bringing about social harmony in society but it plays a disintegrative part as well.

The study concerned here leads from the variety of Islamic culture in Javanese society generally and in the village of Trucuk particularly. The Islamic cultural variety reflects the presence of social groups, strengthened by each group's tendency to hold to its identity. There is a strong orientation towards each own social group, which indicates the presence of sensitivity in its relation with any other social group. In relation with Geertz' orBecause a religion is an ethos bringing to it its followers' quality of strong belief, social difference (in the sense of social conflict) could occur as consequence of religious doctrines being translated or interpreted differently according to each own social group. Difference in translation or interpretation brings about social conflict among social groups. Because religion is regarded as a cultural system, the social conflict is also a collision of cultural values.

In the research concerned there were efforts to view the relation between an entity of tradition in society (and thus part of local culture) and Islamic cultural values which is caused by the occurrence of difference in pattern of action and interpretation of devices of religion or belief used by its practitioners on the face of their social environment. The difference in pattern of action and interpretation is reflected in the social and religious life of the Islamic communities in the village area of Trucuk, Klaten, which are divided more generally into two larger social groups, namely, the social group of the Islamic purification movement supporters and the social group of the social tradition supporters. They both claim to embrace Islam but in their social and religious or belief-related life they hold to different patterns of action and interpretations or, in other words, they have different cultural systems.

More specifically, the research concerned here leads from a social phenomenon, namely, Muhammadiyah as

${ }_{1}^{1}$ Abangan refers to Javanese people who embrace Islam without obeying Islamic laws by not doing the daily prayers, for example. Santri refers to faithful followers of Islam. Priyayi refers to the nobility, civil servants, and employees of private companies. 
Islamic purification movement (or pure-Islam movement) which persistently attempts to eradicate the social tradition slametan, which it considers irrational. By endlessly attempting to conduct the eradication, the Muhammadiyah movement (of Islamic purification) stresses that some social traditions do not conform to Islamic laws. When rites are attached to the laws and applied in the form of moslem behavior, it would form normative piety which is interpreted by Woodward (2004: 6) as a set of behavior bestowed by Allah through a messenger, the Prophet Muhammad.

Muhammadiyah considers that such social traditions are not ways which are Islamic in nature; instead, they are ways that would just menyuburkan practices which do not make sense. That is why Muhammadiyah's attitude to social traditions shows an unfriendly face (Abdurrahman, 2003: 22). It could be stated that the relation between Muhammadiyah as Islamic purification movement and social tradition all this time has appeared stiff. Muhammadiyah people are reluctant to enter the circles of social tradition. Practitioners of social traditions are also reluctant to enter Muhammadiyah circles, which they consider terrifying.

The endurance and life dynamics of the Muhammadiyah Islamic society lie on its purist attitude in the course of upholding the Islam religion (Peacock, 1978). However, since early in its beginning, Muhammadiyah has received reaction from the circles of traditionalists supporting social traditions because of its conservative thinking and attitude (Thoyibi, 2003: 189). Such social relation causes the growth of a conflictual nature in the practitioners of the Islamic purification movement which is reflected in its ideology and identity on the face of the social tradition in Trucuk. Therefore, the problem in the study concerned here was focused on (1) the form of social tradition, (2) the form of the Islamic purification movement in conducting its penetration into social tradition, and (3) the relation between social tradition and the Islamic purification movement.

\section{Theoretical Basis}

To view the problem involving the two entities of the Islamic purification movement and social tradition, in the study concerned here a theoretical basis covering theories of ideology and identity is required.

\subsection{Identity}

Something is said to have identity when it calls itself in terms of a certain category. Because anything does not stand alone, something outside it would put it in a certain identity category (Abdilah, 2002: 26). Sex, color of skin, language, religion, national flag, ethnicity, and art are certain identity categories. In Islamic religious living in Indonesia, a number of sects or organizations like Nahdatul Ulama, Jamaah Islamiyah, Majelis Mujahiddin Indonesia, Nahdatul Anwar, Ahmadiyah, Majelis Tabligh, Syiah, Majelis Tafsir Al-Qur'an, Salafiah, Muhammadiyah, Hisbul Tahrir, Ichvanul Muslimin, and others are known. They are identity categories of Islam followers.

The search for an identity is closely related to the domains of humanity and human psychology. At the level of humanity, a problem that modern people are faced with is the erosion of aspects of humanity from their human selves, which results in the disappearance of their identity as members of humanity. So too is the case at the level of psychology; the awareness or belief of something that one is faced with in one's journey in life always undergoes continuity and alteration. This also indicates that when one seeks the meaning of an identity, it would always change. Therefore, Piliang (1999) stresses that the tracing of the meaning and concept of identity is an effort which is continuous and endless like a winding road. Likewise, Hall (1996: 160) mentions that seeking the meaning of identity is something that is never perfect, always being in the process and always being built from within.

Besides in psychological terms, in sociological terms, Giddens (1991: 75) also discusses the matter of identity, that is, more particularly, self-identity, which is understood as the result of using one's skill of narrating about oneself and telling the feelings and the changes which occur in one's life story. The narration about identity is used to answer questions like "What happens?", "How is it done?", and "Who becomes something?", for example. Identity narration is constructed by one to shape oneself in the course of development from past experience to the future.

Another view of Giddens' about self-identity concerns what one thinks of self-identity in one's capacity as a person. In connection with it, Giddens also argues that identity is not a group of traits which one possesses nor it is something that one possesses. It is a mode of thinking about one's own self. It is only that what one thinks of always changes in space and time. Using that argument as a step point, Giddens describes identity as a project. An implication is that identity is something which one generates, which is always in a process, and which goes forward instead of backward. That opinion implies that identity is not a final and static entity; instead, it is a dynamic problem. Then this concept of identity as social construct has been used to explain a movement to purify Islam and tradition of society. 


\subsection{Ideology}

Ideology is often understood in differing perspectives. However, a neutral idea about ideology is that it contains coherent, comprehensive, and clear pillars. Not only ideology could be understood but also it has the pretension of being able to be practiced by society. That is the requirement that quarrantees human faith in ideology before it is practiced in the field. Generally, ideology could be understood as a believable set of systems. Bell (1962: 17) also uses the terminology of ideology as a complexity of ideas that in a specific way makes people interested in it. In the nineteenth century, the idea of ideology was considerably used and it was considered a set of belief systems but also a group of ideas increasingly becoming known in society.

In the beginning, the term ideology was used by de Tracy (1754-1856) to mean the science of ideas. De Tracy follows the French enlightenment tradition of thinking that reason is the main instrument of happiness. His understanding seems to have a positive connotation, namely, ideology as the right science to concern and overcome religious and metaphysical prejudice for society's education. Though deep reflection (or preoccupation) has been started far earlier but there has been a phenomenon that makes a relation between intellectual legitimation of social domination and various sources of mental deviation in empirical sciences as long as there are groups of society members. An interesting analysis on ideology has appeared in modern society after a disintegration of society occurred in the middle ages. The occurrence of the disintegration has encouraged the struggle to liberate the bourgeoisie from the shackles of feodalism.

A representative of the bourgeoisie, Machiavelli (1469-1520) was the first writer who discussed problems related to the phenomenon of ideology. Though in his writings he does not use the term ideology, his concepts which are oriented to ideology always appear. He relates the tendency of human evaluation with personal taste and interest. Another idea of his is about the relation of religion with power and domination. Religion only functions to venerate modest people while people who put more importance on worldliness are looked down upon. His next idea concerns his consideration for the acquisition and maintenance of power (Larrain, 1996: 7-9).

In its development, the term ideology has been used with various senses and widely exploited in daily life with differing meanings, especially in the political field. However, in the field of the social sciences, ideology as a concept appears equivocal and elusive so that it is also relatively difficult to be used accurately. Therefore, the function of the term ideology often depends on the meaning given to it. For example, ideology is understood in a neutral sense or in the sense of the view of classes in life with, as stated by Gramsci, ideology functioning as sticking cement though not all manage to be stuck to one another or, in another view expressed by Goldman, ideology is useful to unify class members with various aspirations and feelings which usually occur in the class concerned (Larrain, 1996: 112).

Discussions about ideology are reviewed considerably in the theory of the sociology of knowledge pioneered by Karl Mannheim (1893-1947). The theory is a theory which endeavors to examine the relation between knowledge and life and between thought and action under the influence of social prejudices. In addition, the sociology of knowledge is also a method that attempts to make research on forms of human intellectual development contextually (Mannheim, 1985: 287). The revelation of ideology depends on the appearance of problems when social structures begin to express themselves in statement structures. The social structures meant here are social situations and phenomena which survive with the social phenomena being those in a set of relations with the system of values and forming a system of knowledge which society believes.

\section{Research Method}

The research concerned here was conducted in Kecamatan Trucuk, Kabupaten Klaten, Propinsi Jawa Tengah, Indonesia. The research area is about fourteen kilometers east of the city of Klaten. The area of Kecamatan Trucuk is a fertile one for the development of the Muhammadiyah movement as a movement of Islamic purification. Besides, the same area is also a fertile one for the development of tradition in society. The research concerned here used an ethnographical approach. The research subjects were supporters of the Muhammadiyah movement, namely, the Muhammadiyah da'is (or preachers), takmir (or managers) of a mosque, and teachers. The research subjects also included supporters of social tradition, who were, among others, farmers, dalangs (puppet masters at traditional leather puppet plays), sindhens (women singing at those plays), kyais (senior teachers of Islam), caretakers of sacred tombs, and priests.

The research data were compiled by means of direct participatory observation in the field. In addition, the data compilation was also done via in-depth interviews. The data analysis went from the phases of data collection and data reduction through finally to that of conclusion drawing. Triangulation was done to check data validity. 


\section{Research Results}

\subsection{Social Traditions}

One of the traditions in the local culture of Javanese society which is still often practiced by village farmer communities is the one called slametan. Slametan is a form of social activity materializing as a rite which is traditionally conducted. Many farmers still hold the rite of slametan for various occasions. The slametan rite is still regarded as important activity for the purpose of seeking security and peace in life and helping nature to maintain its equilibrium. The equilibrium in nature refers to the maintenance of harmonious relation between two kinds of nature, the smaller nature and the larger nature. The former is of any human being. The latter is of God, the devil, or the spirits of dead people. The smaller nature tries to obtain the protection of certain security while the larger nature protects the security of the smaller nature on the condition that both are in harmony with each other. If there is disharmony, a disaster would happen to the smaller nature. Therefore, Javanese people hold slametan in order to harmonize their relation with the spirits of dead people which have power over their village (Geertz, 1960). Now, that belief has begun to shift to that slametan harmonizes the relation between the human beings concerned and God.

The most important aspect in the rite of slametan is a myth in belief. Without it, the rite would be spiritless, which means that it would be easily abandoned by its supporting society. Therefore, the rite of slametan is regarded as one of the firmest elements of Javanese culture in comparison with other elements of Javanese culture. However, there is a tendency for it to undergo shifts from time to time though essentially it still has the same form from time to time. The shifts result from the influence of the scientific and technological development causing the Javanese society to think more rationally.

Though the slametan rite has undergone shifts, it is still held by Javanese society in both cities and villages. Javanese people have the myth in the belief that spirits of dead people could be invited to communicate with them. When Javanese people hold the slametan rite, it is always preceded by invitations to neighbors and relatives as well as spirits of dead people. As an actualization of the feeling of communicating with spirits of dead people, the menu of the refreshment served is in the form of an offering. The offering has various forms and its purpose is to be presented to spirits of dead people. Thus, the slametan rite is not only for fellow human beings but also for beings commonly invisible to human eyes. This is what makes the smaller and larger nature become harmonious.

As for the purpose of holding the slametan rite, it is to seek safety and peace of mind and to safeguard the preservation of nature. It means that the purpose of the slametan rite is to receive safety for both the holder of the rite and the person for whom the rite is held. For example, when holding the slametan rite for someone who has just died, its goal is that both people who are still alive in the world and spirits of dead people in the afterlife are in safety.

In the beginning, slametan was a rite belonging to the Javanese people who were followers of animism and it was accompanied with Hindu incantations. When the religion of Islam entered Java, members of the group known as Wali Sanga, who were early preachers of Islam in Java, made a certain approach. Not all the elements of the rite were wiped out but the Hindu incantations were changed and adjusted to prayers of Islam. Then it is still common to offer prayers for the sake of a Javanese who has died through the slametan rite. For example, the priest leading the slametan held on the occasion of Bapak Kartoprawiro's death would speak as follows,"May the faults of Bapak Kartoprawiro's spirit be forgiven, his sins be absolved, and his grave be made spacious, dan may he be given a good place, which is Allah's heaven." After delivering the introductory words, the priest would lead the prayers offered for the sake of the deceased in Arabic. In the prayers, the words bismillah, Mukammad, alkamdulilah, and ngalamin are heard. It means that the rite is accompanied with Islamic prayers.

Though having been converted into Islam, so to speak, the name of the rite remains the same, namely, slametan. That is why in it Javanese custom and belief mix with Islamic tradition into one whole unity. The slametan tradition is inseparable from the Javanese people's life movements. Yasadipura, a bard in the kingdom of Mataram, states that slametan is meant to be a token of thankfulness to God, who has bestowed various blessings, good health, prosperity, and peace of mind and has made this life of ours far from disasters. Therefore, the slametan rite is common to be held by someone who is in the midst of some good fortune like abundant harvest, having wares sold in great quantity, winning a lottery, being appointed regent, completing house building, graduating from a school, becoming a champion in a competition, and so on. However, one who has got some misfortune like falling from a vehicle, having an accident on the road, being ill for months, losing money, one's goats being stolen by thieves, and so on also holds slametan. Thus, the slametan rite is held by both Javanese people who are in good fortune and those who are in misfortune. Both a happy situation and a sad one are actually indications of conditions which are not normal. Both the happy feeling because of receiving something and the sad feeling because of losing something could endanger the life of Javanese people. 
Therefore, in order that everything is always in safety, the slametan rite should be held.

In the view of Javanese society, in one's life in the world one commonly goes through several stages, namely, being a foetus in one's mother's womb, being born as a baby, growing into a youngster, turning into an adolescent, and becoming an adult, getting married, getting old, and finally dying. Those are the stages of human life. When one moves ahead one stage, it means that one leaves one stage. A baby who is born into the world is moving ahead one stage. It leaves an environment which it has known during its mother's pregnancy for the environment of a world which it has not known yet. Likewise, when one dies, one leaves the worldly environment one is familiar with to come to the environment of the afterlife one is not familiar with yet. Each time a human being goes ahead one stage, it means that the human being concerned has entered a stage he or she is not familiar with yet. In addition, according to Javanese belief, events related to someone's life such as pregnancy, birth, marriage, and death are not coincidences. In such events, he or she enters something called tense and critical moments and the person concerned even gets into a weakened and sacred situation. Such a situation could cause social danger to occur and in turn cause the social order in the form of equilibrium of nature to be disturbed. According to the belief of Javanese people, in such moments it is necessary to hold slametan in order to be safe and to avoid undesirable things.

In the area of Trucuk there are various kinds of slametan. They are, among others, (1) slametan in relation with ziarah (or pilgrimage at a burial place), (2) slametan in relation with nature, and (3) slametan in relation with the human life cycle. Slametan ziarah is held by conducting a certain rite with people collectively or individually participating in it at sacred tombs. Slametan in relation with nature is a rite held by agrarian communities to preserve the life of rice plants. There are three kinds of this rite held by farmer communities; they are tedun (or the rite for the planting season), metik (or the rite for the harvesting season), and giving homage to Dewi Sri (or the rite before harvest). Slametan in relation with the human life cycle is a rite commemorating the human life cycle. This rite is used to honor important events in the life of Javanese people from births, circumcisions, and weddings to deaths. They are all referred to as social traditions here.

\subsection{Forms of the Islamic Purification Movement}

The Islamic purification movement in Trucuk is pioneered by the religious institution Muhammadiyah, which attempts to purify Islam back into the original coming from Saudi Arabia. The Muhammadiyah movement is a religious movement built up to apply the rules stated in the Islamic holy book. Institutionally, the Muhammadiyah movement is coordinated from its head, territorial, regional, branch, and sub-branch offices.

The main issue raised in various activities of the movement is to keep away from the social tradition in the local culture of Javanese people called slametan though it is still firmly rooted in the life of society in the village of Trucuk. According to Muhammadiyah thinking, various traditions in society are not in line with the teachings of Islam. In such thinking, the funeral rite, for example, is regarded as an irrational form of worship.

\subsubsection{The Sunday Morning Pengajian}

The Sunday morning pengajian (or communal religious study) takes place in the grounds of the Muhammadiyah school building from 7.00 to $8.00 \mathrm{a} . \mathrm{m}$. It is usually attended by around 700 people consisting of men and women. Many people come from outside the area of Trucuk because the Sunday morning pengajian builds up the purity of their belief in Islam the religion (Ostertag, 2014:45). This proves that the Sunday morning pengajian is a base for the Islamic purification movement.

The dais (or preachers of Islam) brought there are those already capable of practicing the pure teachings of Islam. Whenever there is a dai who turns out not to be teaching pure Islam, he would not be invited anymore in the future. Therefore, the Sunday morning pengajian invites dais from such sufficiently distant places as the Kecamatans of Klaten, Bayat, Kalikotes, Jatinom, Ngawen, Karanganom, Ceper, Cawas, and Delanggu. Even dais from Yogyakarta, namely, Sunardi Sahuri and Didik Purwodarsono, also participate as main speakers in the Sunday morning pengajian.

They are preachers who are consistent in disseminating pure Islam and not traditional or local Islam which is greatly mixed with local culture. In preaching in the Sunday morning pengajian, almost all the dais refuse being given money to pay for transport expense. In fact, there are dais who even contribute money to support the running of the Sunday morning pengajian each time they come to speak there. It proves that in the Islamic purification movement there are no commercialized religious acts but only religious ones willingly done. 


\subsubsection{The Tariih Movement}

The term tarjih refers to something held up for excellence or a matter put forward to be discussed together by leaders and members of Muhammadiyah from the head down to the sub-branch levels. For example, such a tradition of the Trucuk society as slametan has all this time been a matter often discussed by Muhammadiyah. The matter of the social tradition has then been raised in the tarjih pengajian of Muhammadiyah, from the regional (kabupaten) level, down to the branch (kecamatan) level, and finally the sub-branch (village) level.

Pengajian tarjih of the regional level is held once every two weeks by head officials of Muhammadiyah of the regional level. The locations used for the pengajian are in the areas of kecamatans. In Kabupaten Klaten, there are twenty-six kecamatans. In a year, the kecamatans would be occupied in turns for pengajian tarjih of the regional level. In participatory observations, the writer attended pengajian tarih in the Kecamatans of Manisrenggo, Prambanan, Karangnongko, Jatinom, Delanggu, and Wedi. Each time the pengajian was attended by members of the Muhammadiyah movement around 3000 in number consisting of men and women. The number could be known relatively accurately because it is based on the quantity of refreshments provided by the organizing committee; there were 3000 boxes of refreshments.

A text for pengajian tarjih is prepared by a team called Team Five. The team consists of members of Muhammadiyah considered seniors. On the average, they are between 55 and 70 years old, possess expertise concerning the holy book, and have once studied at a school of religion. They have virtuosity in delivering treatises about Islam the religion. Therefore, they possess sufficient credibility for the task of writing the tarjih text.

In form, pengajian tarjih resembles pengajian akbar (akbar means "great"). There is a platform or stage specifically to be occupied by Team Five and head elements of the Klaten Muhammadiyah. In front of the stage, there is a podium and on the right and left of the stage, loudspeakers are installed. In front of the podium, a large mat is spread to be sat on by the audience of the pengajian. When pengajian tarjih was held in Kecamatan Manisrenggo, it took place in the yard of a house belonging to a cow merchant; the yard was 1000 square meters in area. Because it took place in a yard, in anticipation of coming rain, tents and tarpaulin shelters were set up. Pengajian tariih could also be held indoors; the one in Kecamatan Tulung took place inside a sports building and the one in Kecamatan Wedi took place inside the Jami Mosque. In pengajian tarjih, one of the members of Team Five stands on the podium to read the tarjih text and give some explanation.

According to what is told by a committee member from Kecamatan Karangnongko, the cost of holding the pengajian amounts to two million rupiahs (equal to two hundred US dollars). Such a large amount is used to pay for the expenses of some needs, which are, among others, renting a tent 600 square meters in area, renting a sound system, providing refreshments, and arranging a stage. That large amount of fund is obtained through contributions from Muhammadiyah sub-branches in villages. To get ready the facilities and resources of pengajian tarjih, a committee is formed, involving head elements of Muhammadiyah of both the branch and sub-branch levels. The committee consists of around fifty people on duty in various divisions, which are, among others, the stage, sound system, tarjih text, guest welcomer, refreshment, tent and tarpaulin, mat, vehicle parking, praying and toilet water, money contribution box, and cleaning divisions.

Pengajian tariih is opened by saying basmallah together at precisely $1.00 \mathrm{p.m}$. The second item in the program is the first session of pengajian tarjih itself presented by the tarjih chairman. Before that, the committee distributes the tariih text to the whole audience. Usually the Muhammadiyah members look enthusiastic in attending pengajian tarjih. In the pengajian, often the audience is given twenty minutes as opportunity to ask questions. After the finish of the first session at about 3.00 p.m., the adzan (or call to prayer) is given to signal that the asar (or afternoon) prayer would be done together. After the finish of the asar prayer, the program is directly continued to the second session of pengajian tarijh. The committee again distributes the tarjih text to the whole audience. The topic of the tarijh text in the second session differs from that in the first. The second session is conducted in the same way as the first. At exactly 4.00 p.m., pengajian tarjih is finished.

\subsubsection{The Social Education}

In the organizatory body of Muhammadiyah, there are a chairperson and a secretary as well as other head elements acting as heads of sections supervising various fields from that of dakwah (or preaching) to that of economics. They are elected by members with the consideration that they are capable of disseminating the religion of pure Islam. On the average, they are Muhammadiyah dais. In the area of Kecamatan Trucuk there are about fifty Muhammadiyah dais. They are the backbone of the Islamic purification movement in Trucuk. 
Almost every night they leave home to deliver pengajian for social education to groups of society members in the villages in the area of Kecamatan Trucuk. Each of them departs from home alone and is unwilling to be fetched from home or escorted home. Without receiving anything in return, they work willingly to spread pure Islam. Whenever there are society members who attempt to give something in return in the form of money or goods, they refuse it politely.

This work that they do has gone on for years without causing any tiredness. In fact, both the educator and those undergoing education do not even look exhausted. All this time, both those involved as the educators and those involved as those being educated have never felt how many years the pengajian being attended has been running. Like a ball rolling down sloping ground, the pengajian for the education of society continues to run, even when it rains.

\section{Discussion and Implication}

\subsection{Revelation of Identity}

The self-identity of the Islamic purification movement is reflected on its institutional characteristics. The characteristics could be distinguished into three forms of movement: (1) Muhammadiyah as an Islamic movement, (2) Muhammadiyah as an Islamic dakwah (or preaching) movement, and (3) Muhammadiyah as a tajdid (or reformation) movement (Pasha, 2003: 160). Muhammadiyah as an Islamic movement is motivated and encouraged by the teachings in the holy book. This Muhammadiyah movement would attempt to present the face of Islam in a form which is actual and could be absorbed, felt, and enjoyed by society as rahmat (or blessing) for the whole universe. Then Muhammadiyah as a movement of preaching Islam is known as a preaching movement that invites what is good and keeps away from what is otherwise.

To invite what is good, Muhammadiyah plays a part in the midst of society by building various humanitarian endeavors like schools, hospitals, and orphanages, among others. The most recent activity of Muhammadiyah in Trucuk in making the Muhammadiyah institution prrogress through schools is building, among others, thirty kindergartens, six elementary schools, and one junior high school. In the field of health, it runs an emergency clinic very Sunday. The clinic is managed by a Muhammadiyah doctor and it is open at the same time as the Sunday morning pengajian and it takes place in a room at a Muhammadiyah junior high school building.

Muhammadiyah as a tajdid movement has two meanings, namely, (1) religious purification and (2) improvement, development, and modernization. The expression religious purification refers to the preservation of Islamic teachings originating in the holy book. The expression improvement, development, and modernization (through education) refers to returning to the teachings of Islam with a fast hold on the holy book and being cleansed from the elements of social tradition (Alwi, 2014: 68)..

This identity of the Islamic purification movement is also observed in the behavior of Muhammadiyah people in Trucuk. Besides returning to Islamic laws in the matter of worship and its rituals, they attempt as hard as possible to eliminate social traditions considered not conforming to the teachings of the holy book. In their life in society, they are often invited to come to slametan but they always refuse. They consider that slametan is a tradition of their ancestors and it has been used to worship idols. In addition, slametan is not a teaching from the holy book. Thus, the identity expression is related to interests, in line with Berzonsky (2014: 96), in this case, the interests of the Islamic purification movement.

That social reality indicates that the identity of the Islamic purification movement has to directly stand face to face against that of the social tradition which is still filled with fertility. The two entities turn out to be equally strong so that it causes a cultural conflict, as in the case of slametan. Whatever is the case, the identity is formed and communicated by its meaning (Chua, 2013: 57). One side wishes to abolish something while the other wishes to preserve it. Thus also it is actually described that in the village society of Trucuk, Klaten, there is an identity struggle between two social groups. Because each is putting its identity at risk, as a result it is difficult to unite the two sides in the cultural conflict. Huntington (1993: 1) states that the occurrence of cultural collision caused by, among others, difference in culture is not just actual in nature; it is more basic in nature.

\subsection{Revelation of Ideology}

The revelation of ideology depends on the occurrence of the matter of when social structures begin to express themselves in statement structures. The social structures meant here are social situations and fenomena which are alive, namely, social situations and fenomena which are in an order of relations with a system of values (which belongs to culture) and form a system of knowledge that society believes in. Take, for example, Islamic people who belong to Muhammadiyah and are very dominantly influenced by one of the visions of the Muhammadiyah institution, namely, the 
eradication of irrational worship. The vision seems to have been made an ideology. Consequently, many moslems from the Muhammadiyah side hold fast to that vision.

The social structures indeed influence the statement structures, as seen in the expression of action and strategy chosen by the Muhammadiyah institution. This is seen in the whole perspective of knowledge, experience, and action of the Muhammadiyah Islamic people who are sufficiently consistent with each other in delivering their perception and statement about their position against social tradition. Their assumption against social tradition in the perspective of Juergensmeyer (2000) is a form of terror in the name of God. The revelation of the ideology of the Muhammadiyah moslems is implied in the relation between religion and ideology stated by Turner (in Morris, 2003: 50). In Turner's view it is mentioned that ideology and religion form the base of social integration both as social glue and as social opium. In addition, religion is the principal source of class solidarity.

The ideology revelation is often thrown into the forums of the Sunday morning pengajian, the pengajian tarjih, and the social education previously mentioned, which are loaded with the eradication of social tradition. Like people campaigning, those involved in the forums obtain sympathy from society, both Muhammadiyah society in particular and Islamic society in general. Therefore, these forums have become chosen communication forums (Millie, 2013: 271); they have even become the backbone of the Islamic purification movement because routinely for the last twelve years the movement has gained masses. It is proven because during the last one year, the writer attended those forums and the jamaah (or participants) have not been decreasing in number. The followers of Muhammadiyah as an Islamic purification movement have become increasingly greater in number.

\section{Conclusion}

The Islamic purification movement, in line with its ideology and identity, attempts to bring back the pure teachings of Islam in accordance with its holy book. The movement takes the form of a penetration into the social tradition in Trucuk. The Muhammadiyah community in the area of Trucuk remain insistent on the formalization of the laws of Islam as the form of its ideology, which means the purification into Islam which is clean from the social tradition dirt. Therefore, many Muhammadiyah Islamic people in that area in their form of identity do not make use of any access to any social tradition though the tradition is still thick in village society or at least it is still fertile in the Trucuk area. For example, when faced with occasions to commemorate such as birth, circumcision, marriage, and death, Muhammadiyah moslems do not practice the slametan tradition as many other Javanese people around them and in other areas do.

Though the practitioners of the Islamic purification movement have kept away from social tradition, it is a fact that social tradition is becoming increasingly more alive in the Trucuk region. At first, early in its appearance, the Islamic purification movement was an anticipation of the social and political signs at that time. As such movement, it certainly has a number of agendas concerning the social traditions not considered Islamic. It is to anticipate the many elements of irrational belief practiced in Javanese social tradition.

The purification movement conducted by means of putting in front the domination of the laws of Islam could not be accepted by members of the Trucuk society who have long preserved and nurtured tradition in society. The laws of Islam standing face-to-face against social tradition is a form of actual confrontation. Therefore, the occurrence of tension in the relation between supporters of the Islamic purification movement and supporters of social tradition in the area of the village of Trucuk could not be avoided. Even now, the efforts by the Islamic purification movement in Kecamatan Trucuk to eradicate social tradition are still going on. However vigorous the Islamic purification movement has been, social tradition still leads a lush life in Trucuk.

\section{References}

Abdillah, S.U. (2002). Politik Identitas Etnis: Pergulatan Tanda Tanpa Identitas. Magelang: Indonesiatera.

Abdurrahman, M. (ed.). (2003). Muhammadiyah sebagai Tenda Kultural. Jakarta: Ideo Press.

Alwi, A.Z., Bakar, N.A.B., Subki, R.N. (2014). "Islamic Faith in Malaysia: Current Issues and Challenges". Mediterranean Journal of Social Sciences, Vol 5 No 20, pp. 62-70.

Bell, D. (1962). The End of Ideology. London: The Free Press.

Berzonsky, M. D. and Dennis R. P. (2014). "Identity Processing Styles and Value Orientations: The Mediational Role of Self-Regulation and Identity Commitment". Identity: An International Journal of Theory and Research, Vol 14, Issue 2, pp., 96-112

Chua, J. M. (2013). "A Sketch for a Ricoeurian Hermeneutics of Religious Identity". Journal for the study of Religiosn and Ideologies, Vol. 12, No. 34, pp., 57-80.

Gertz, C. (1960). The Religion of Java. Chicago: The University o Chicago Press. Jaya.

Giddens, Antony. (1991. Modernity. Gibb, HAR. 1960. Shorter Encyclopedia of Islam. London: EJ Brill Luzac \& Co. 
Hall, S. (1996). "New Etnicities", in D Morley and DK Chen (ed.). Stuart Hall. London: Routledge.

Huntington, S. P. (1993). "The Clash Civilization". Foreign Affair, Vol. 72, No. 3, Summer, pp. 22-49.

Juergensmeyer, M. (2000). Teror in the Maind of God: The Global Rise of Religious Violence. Berkeley and Los Angeles: University of California Press.

Larrain, J. (1996). Konsep Ideologi. Terjemahan dari The Concept of Ideology. Yogyakarta: LKPSM.

Mannheim, Karl. (1985). Ideology and Utopia, An Introduction to the Sociology of Knowledge. Wilmington, Massachusetts: Mariner Books.

Millie, J. (2013). "The situated listener as problem: 'Modern' and 'traditional' subjects in Muslim Indonesia". International Journal of Cultural Studies, Vvol. 16, No. 3: pp. 271-288.

Morris, B. 2003. Antropologi Agama: Kritik Teori-teori Agama Kontemporer. Yogyakarta: AK Group.

Ostertag, S. F. (2014). "Becoming Pure: The Civil Sphere, Media Practices and Constructing Civil Purification". Cultural Sociology Journal, Vol. 8, No. 1, pp., 45-62

Pasha, M. K. dan Darban, A.A. (2003). Muhammadiyah sebagai Gerakan Islam dalam Perspektif Historis dan Ideologis. Yogyakarta: LPPI Universitas Muhammadiyah Yogyakarta.

Peacock, J.L. (1978). The Muhammadiyah Movement in Indonesian Islam: Purify the Faith. CA: Menlo Park.

Piliang, Y.A. (1999). Sebuah Dunia Yang Dilipat, Realitas Kebudayaan Menjelang Milenium Ketiga dan Matinya Posmodernisme. Bandung: Mizan.

Thoyibi, M (et. al.) (ed.). (2003). Sinergi Agama dan Budaya Lokal: Dialektika Muhammadiyah dan Seni Lokal. Surakarta: Muhammadiyah University Press.

Woodward, M. R. (1989). Islam in Java: Normatif Piety and Misticism in the Sultanate Yogyakarta. Tuscon: The University of Arizona Press. 